\title{
The STEAM Education Mode to Training Interdisciplinary Talents
}

\author{
Yuan Zhang ${ }^{1, a}$,Jing Zhang ${ }^{2, b}$ \\ ${ }^{1}$ School of Art, Xi'an University of Technology, ShaanXi, 710032, China; \\ ${ }^{2}$ School of Art and Design, Xl'an Technology University, ShaanXi, 710048, China; \\ a569158405@qq.com, bjingzhang_84@126.com
}

Key words: STEAM, Education mode, Multi-skill, Training.

\begin{abstract}
The article base on the perspective of the STEAM education, to analyzed connections of the course system and construction of practice, it is pursued to build to innovative talents cultivation system with combine the art and science, to satisfaction society development demand.
\end{abstract}

\section{Introduction}

The STEAM education mode purposed to solve practical technical problems with the innovative ability based on science, technology, engineering, art and mathematics. In Chinese, 《National Medium and Long-term for Education Reform and Development (2010-2020)》, it also stress that the college students' practical ability as well as their innovative spirit ${ }^{[1]}$. With the further Chinese market and economy reform, the STEAM education mode more and more utilized in high education of china. Because the Chinese elementary education mode is not accord with modern society development. But the STEAM education mode as a new teaching mode have profound significance which has broader perspective and multiple training means should cultivate students' practice, self-study and innovation ability etc.

As a higher education institution west of china, Xi'an University of Technology tries out STEAM education mode which combining of science and art, teaching and Practice, to construct research university with characteristic regional features.

\section{The Idea of STEAM Education}

The STEAM education was introduced by American government at first, which is praised as quality-oriented education of America. In fact, the STEAM mode is the abbreviation of five words: Science, Technology, Engineering, Arts and Mathematics, which it advocates the all kinds of course intersection and cultivates students to comprehensively grasp knowledge and skills ${ }^{[2]}$. In the STEAM education mode, The students can positively study in different environment, and increase innovate abilities of students and problem-solving abilities, at the same time, it can be let the students learn about some factor of technology and to analysis problem. So, The mode of education could motivates students to become multi-skill talents with scientific spirit train their brains, engineering knowledge laying the foundation, artistic ability endowing originality, it can be improve the comprehensive ability of the student and training full-talent to service economic construction of country ${ }^{[3]}$.

\section{Current Situation of STEAM Education}

At present, the STEAM educational mode is still at an early stage from theory to practice in Chinese, 
it has a lot of problems of relevant education policies, promotion of universities and social resources. For example, The first, the root problem is which the national education reform department have been insufficient, to leads the STEAM education mode has not been deeply infiltrated into course construction and implementation ${ }^{[4]}$. The second, The STEAM education mode is lacking Chinese characteristic courses and innovative practice. At last, the teachers usually lack the teacher recourse of the STEAM training. And the new curriculum's implementation needs to solve textbook's problem and teaching resources development. Therefore, confront educational mode of interdisciplinary, how to improve the quality of teaching is a biggest problem at current.

\section{Training of the STEAM Education}

\section{Course System}

1. general education. it is hot issue of higher educational research in recent years. The Chinese disvalues liberal education, the students usually lack liberal education. But the STEAM education takes on a situation of diversity, mainly involves reform of course system, the way of option, organization set up and so on. How to improve the overall quality of the students is a key issue. Firstly, the school should carry out the " $1+2+1$ " undergraduate teaching platform. For example, in the first grade, all students have a systematic study the basic courses about design, That is the school must breaks down the subject boundary and centers on specific issues. Secondly, professional course system setting, the curriculum reform must connect with new and old curriculum. Making the use of science with technology, engineering, mathematics and other subjects of knowledge to solve problems and realizing the educational target.

2. course setting. The STEAM education mode is an initial development stage at present, the existing course teaching resources are lack of standardization, and it is difficult to formation a scientific and perfect course system ${ }^{[5]}$. The school try to changes traditional teaching concepts and gradually develops excellent course resources to provide education mode for STEAM. Firstly, Xi'an University of Technology gradually starts general education. For example, opening humanistic courses, natural science courses as well as engineering courses, it is purpose to cultivate students' Comprehensive ability and creative thinking.

The school also tries to establish specially management institution. Secondly, the university activity developing course resources information, allow students to know about course arrangement, preparation before class, courseware exhibition, after-class homework and discussion. Meanwhile, building the online study platforms, such as Demo class, network course and other massive open online courses. Some excellent courses of national level, provincial level become students' learning resources. Lastly, the university provide a chance of innovate practice for the students with the engineering training center and innovation labs.

\section{Practice teaching}

With the development of the social, practice education is an important part at the education system. Because it increase the student's innovate spirit and abilities. Especially at the STEAM education, it pay more attention to practical ability. But the student of practice ability and innovation ability cannot meet the demands of the society at present. It is necessary to establish off-campus practice bases and in-campus laboratories. Meanwhile, Xi'an university of technology actively explore the teaching reform in the practical training, including integrate practical teaching content, to let the practical teaching becomes make effective on STEAM education mode.

Xi'an university of technology have already vests more than 6 million Yuan to establish experimental teaching centers, innovation experiment zone for the undergraduate student, in order to meet students' needs of innovation. And establishes all kinds of labs, including model lab, rapid 
prototyping lab, motorcycle model lab, photography lab and sculpture metal processing lab etc. Except students of grade 1, the other grades must have all innovation practice at the last three weeks every term. The students are required to complete innovation task in practice class, these training activities may helped student to combining theory with practice, and lead to the professional guidance for different majors student.

Off-campus practice training is based on industry-university-research cooperation which is the trend of educational development. So, the school relying on its advantage and combining the enterprise, to expand innovate practice for the student. At the same time, it also transports student resources to society, to profession guidance for student. At present, the Xi'an university of technology have established practice teaching bases at Chong Qing, Jiang Men, Urban Homes Decoration Co, Fu Ping Pottery Village and so on.

\section{Project teaching}

The STEAM education mode not only learning knowledge proposes, but also stress the practice teaching. The students will apply their knowledge to solving problems and innovation in practical course. This learning method will have a profound influence on their future work. At past, the most of college students that they are generally lacking practical chance. Now the school practical actively organize students to develop innovation activities. and to play a very important role in college students' growth. For example, encourage students to apply for technological innovation projects and activity join in university-enterprise research projects, at the same time, combining to the all kinds of competition, combining in-class teaching with after-class practice, to improving the students' innovative and entrepreneurial ability. Second, the school according to the different grade, organization campus activities and social practice, apply lots of opportunities of practice to the student. For example, The college hold annual visual creative competition in year, exhibitions of curriculum, The Science Festival, These competition should providing the stage to the student enabling them to consciously improve innovative education.

\section{Teacher resource}

According to different majors at the STEAM courses, the teachers must rely on the school's characteristic to seek new breakthrough directions, change educational concepts, expand course organization construction and implement relevant research. Besides, the teachers maybe according to interests themselves to form STEAM courses to promote the teacher development. With the development of the teachers impetus to the students' innovation.

\section{Summary}

The universities carries out STEAM education mode, which is combine art and engineering in order to cultivate innovative talents. This education mode will promote the students' employment core competitiveness as well as to fit social development trend at current.

Project: Based on the entrepreneurship drive to the employment talent training mode study

(15JGY29)

\section{References}

[1] Shanming Hu. Influence Factors and Countermeasure Study of Teaching Ability Training of Young University Teachers [D]. Hunan University of Science and Technology, 2012.

[2] Hu Pan, Jiafu Jiang, Zichao Chen. Practical Difficulties and Countermeasures of Chinese STEAM Educational Development[J]. China Information Technology Education, 2015, 09:46-47. 
[3] Guisheng Cao. Primary investigation of Art Education and Science Education [N]. Guang Ming Daily, 2004-02-05.

[4] Shengquan Yu, HuXiang. STEAM Educational Concept and Interdisciplinary Integration Model [J]. Open Education Research, 2015, 04:13-22.

[5] Jiangshan Sun, Yonghe Wu, Youqun Ren. 3D Printing Education Innovation: Maker Space, Innovation Lab and STEAM [J]. Modern Distance Education Research, 2015, 04:96-103. 